\title{
EFFECT OF SUBSTRATES ON NUTRITIONAL COMPOSITION AND FUNCTIONAL PROPERTIES OF PLEUROTUS OSTREATUS
}

\author{
Mbassi Josiane \\ E. G. ${ }^{1+}$ \\ (iD) Mobou Estelle \\ Y. ${ }^{2}$ \\ (i) Ngome Francis \\ A. ${ }^{3}$ \\ iD Sado Kamdem S. \\ L. ${ }^{4}$
}

\author{
1,s Institute of Agricultural Research for Development (IRAD), P.O. Box 2123 \\ Messa Taounde, Cameroon. \\ ${ }^{2}$ Email:josianembassi@yahoo.fr Tel: (+237) 699828847 \\ ${ }^{3}$ Email:ngomajebe@yahoo.com Tel:(+237)678967402 \\ ${ }^{2}$ Department of Biochemestry, Faculty of Sciences, University of Taounde I, \\ Taounde, P.O. Box 812, Cameroon. \\ ${ }^{2}$ Email: estelleyolande@yahoo.com Tel: (+237)698349154 \\ ${ }^{4}$ Department of Microbiology, Faculty of Sciences, University of Yaounde I, \\ Taounde, P.O. Box 812, Cameroon. \\ ${ }^{4}$ Email: sadosylvain@hotmail.com Tel: (+237)670909871
}

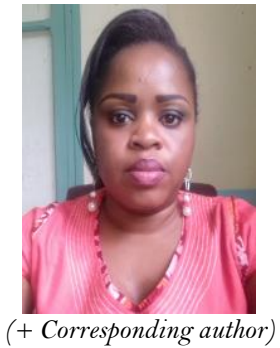

(+ Corresponding author)

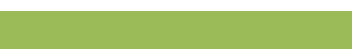

Article History

Received: 27 April 2018 Revised: 8 May 2018

Accepted: 15 May 2018

Published: 31 May 2018

\section{Keywords}

White-rot fungi

Nutritional properties

Biological productivity

Efficiency

Substrates

Yield.

\section{ABSTRACT}

Pleurotus species, commonly known as oyster mushrooms, are edible fungi cultivated worldwide. Pleurotus genus is one of most extensively studied white-rot fungi due to its exceptional ligninolytic properties. These mushrooms have the ability to colonize and degrade a wide variety of lingo-cellulosic wastes with relatively short cycle. The objective of this study was to review published research works on the effect of substrates on nutritional composition and functional property of Pleurotus ostreatus. A literature search was done on the internet and university libraries in this area. It was found that different substrates used in cultivating mushrooms do have effect on the functional, organoleptic and nutritional properties of mushrooms. This review presents a practical checklist of effect of substrates on quality of Pleurotus ostreatus that may help different users.

Contribution/Originality: This study is one of very few studies which have investigated the effect of type of substrate on nutritional composition and functional property of Pleurotus ostreatus.

\section{INTRODUCTION}

Pleurotus species, commonly known as oyster mushrooms, are edible fungi cultivated worldwide especially in South East Asia, India, Europe and Africa [1]. China produces $64 \%$ of all edible mushrooms in the world and $85 \%$ of all oyster mushrooms all over the world (Pleurotus spp.) is also produced in China [2]. Oyster mushrooms is the third largest [3] commercially produced mushroom in the world; however, Sánchez [4] reported that P. ostreatus is the second largest next to Agaricus bisporus in the world market. It consists of a number of different species including Pleurotus ostreatus, P. sajor-caju, P.cystidiosus, P. cornucopiae, P. pulmonarius, $P$. tuberregium, P. sapidus, P. citrinopileatus and P.flabellatus, which have been cultivated in temperate and subtropical regions of the world.

Oysters are naturally found on rotten wood material. The growing and consumption interest of oyster mushroom is increasing largely due to its taste, medicinal and nutritional properties [5]. P. ostreatus demands few environmental controls, and their fruiting bodies are not often attacked by diseases and pests, and they can be cultivated in a simple and cheap way. All this makes $P$. ostreatus cultivation an excellent alternative for production of mushrooms when compared to other mushrooms. Therefore, it is better for unskilled farmers 
than other mushrooms. Mushroom cultivation provides an alternative employment and it contributes to food security to rural disadvantaged groups [6]. These mushrooms have the ability to colonize and degrade a wide variety of lignocellulosic wastes with relatively short cycle [7-15].

Agro-industrial waste is produced in huge amounts, and it becomes an interesting substrate, due its commercial exploitation as well as associated environmental problems [16, 17]. Many studies have been conducted to test the ability of Pleurotus to grow on different agro wastes, such as cassava peels, cotton seed hulls, coffee husks, wheat straw, barely straw, saw dust and sinar straw [4, 18, 19] tomato tuff [20] fruit pulp and peel, coffee pulp, sugarcane residues [21-23]. These by-products are left to rot in the field or are disposed of through burning. These residues associated with mycelium also have a great potential for use as fodder animal and as fertilizer in agriculture [24, 25]. The objective of this study was to review published research works on the effect of substrates on nutritional composition and functional property of Pleurotus ostreatus.

\section{MICRO NUTRIENTS CONTENT OF PLEUROTUS OSTREATUS}

The fructifications of mushrooms are characterized by a high level of well assimilable mineral constituents whose level depends amongs other things, on the species and the age of the mushroom, the diameter of the pilei and the substrate [26, 27]. The distribution of these substances in the fructification varies and their content is usually greater in the pileus than in the stipe [28]. The pilei of Pleurotus osteatus have greater contents of copper, iron, potassium, magnesium, phosphorus and zinc, and the stipes of sodium [29] (Table 1).

\subsection{Phosphorus}

Phosphorus and calcium are minerals more represented in the body. In fact, $80 \%$ of phosphorus are associated with calcium to form bones and teeth. The rest of $20 \%$ is in the blood and soft tissues. This mineral could be assimilated by the body trough nutrition. In a study; Victor and Olatomiwa [30] showed that Phosphorus was the most abundant mineral element in the cultivated mushroom samples. The value ranges between $51.97 \mathrm{mg} / 100 \mathrm{~g}$ to $56.77 \mathrm{mg} / 100 \mathrm{~g}$. Ogundele, et al. [31] reported in a study that phosphorus have a value range to (10.36 and 10.09 $\mathrm{mg} / 100 \mathrm{~g}$ ) for mushroom harvested from hardwood (Anogeissus leiocarpus) sawdust and softwood (Daniellia oliveri) sawdust respectively. Tamiris, et al. [32] also reported that in P. ostreatoroseus mushrooms the macrominerals $\mathrm{K}$ and $\mathrm{P}$ were significant while $\mathrm{Mg}$ and $\mathrm{Ca}$ were determined in minor amounts.

\subsection{Potassium}

In an earlier study, phosphorus and potassium were reported as the most abundant mineral elements in $P$. sajor-caju fruit bodies cultivated on corncobs. It was also reported potassium as the most concentrated mineral element in various species of edible mushrooms Oyetayo [33]; Manzi, et al. [8]. Ogundele, et al. [31] reported in a study that potassium have the highest value $(22.81 \mathrm{mg} / 100 \mathrm{~g}$ and $21.90 \mathrm{mg} / 100 \mathrm{~g})$ for mushroom harvested from hardwood (Anogeissus leiocarpus) sawdust and softwood (Daniellia oliveri) sawdust respectively. This result was similar to the report of Alananbeh et al., in Ananbeh and Almomany [20] who reported that highest value for potassium was obtained from Pleurotus ostreatus harvested from four different substrates. Potassium was reported to be essential for several enzymatic reactions in food, and the quantity in Pleurotus ostreatus makes it good food for people suffering from hypertension and heart diseases.

\subsection{Calcium}

Ogundele, et al. [31] have reported that calcium have a value range to 3.51 and $3.42 \mathrm{mg} / 100 \mathrm{~g}$ for mushroom harvested from hardwood (Anogeissus leiocarpus) sawdust and softwood (Daniellia oliveri) sawdust respectively. Victor and Olatomiwa [30] reported that Pleurotus ostreatus harvested from Pycnanthus Ongoleubis, Ceiba Pentandra and Cananium sp. of Wood type recorded 8.87; 5.37 and $6.85 \mathrm{mg} / 100 \mathrm{~g}$ respectively. 


\subsection{Sodium}

For mushroom harvested from hardwood (Anogeissus leiocarpus) sawdust and softwood (Daniellia oliveri) sawdust respectively, Ogundele, et al. [31] show that sodium have a value range to 3.51 and $3.00 \mathrm{mg} / 100 \mathrm{~g}$. Comparatively, Pleurotus ostreatus harvested from cupuaçu exocarp supplemented with rice bran recorded 30.85 $\mathrm{g} / \mathrm{kg}$.

\subsection{Magnesium}

According to Victor and Olatomiwa [30] the least mineral values were recorded from Magnesium. About 1.25 $\mathrm{mg} / 100 \mathrm{~g}$ was obtained from the Pleurotus ostreatus harvested from hardwood (Anogeissus leiocarpus) sawdust while $1.04 \mathrm{mg} / 100 \mathrm{~g}$ was obtained from softwood (Daniellia oliveri) sawdust. However, Debu, et al. [34] reported that the highest and the lowest (13.31) milligram percentage of magnesium was observed on Swietenia mahagoni and ficus carica sawdust substrates respectively.

\subsection{Zinc}

Pleurotus ostreatus harvested from hardwood (Anogeissus leiocarpus) sawdust recorded $0.96 \mathrm{mg} / 100 \mathrm{~g}$ of zinc as well as softwood (Daniellia oliveri) sawdust Ogundele, et al. [31]. Oyetayo [33] also reported that in $P$. ostreatoroseus mushrooms, among the trace elements, $\mathrm{Zn}$ and $\mathrm{Fe}$ had the highest concentrations and $\mathrm{Na}$, Mn and $\mathrm{Cu}$ were present in small quantities.

Table-1. Micro nutrients content of Pleurotus ostreatus harvested from different sawdust substrates

\begin{tabular}{|c|c|c|c|c|c|c|c|}
\hline $\begin{array}{l}\text { Sawdust } \\
\text { Substrate (\%) }\end{array}$ & $\begin{array}{l}\text { Calcium } \\
(\mathrm{mg} / \mathrm{100g})\end{array}$ & $\begin{array}{l}\text { Sodium } \\
\%\end{array}$ & $\begin{array}{l}\text { Potassium } \\
\%\end{array}$ & $\begin{array}{l}\text { Phosphorus } \\
\%\end{array}$ & $\begin{array}{l}\text { Magnesium } \\
\%\end{array}$ & $\begin{array}{l}\text { Zinc } \\
\%\end{array}$ & References \\
\hline $\begin{array}{l}\text { Pycnanthus } \\
\text { Ongoleubis }\end{array}$ & 8.87 & 4.39 & 11.34 & 56.77 & 3.57 & & \multirow{3}{*}[30]{} \\
\hline $\begin{array}{l}\text { Ceiba } \\
\text { Pentandra }\end{array}$ & 5.37 & 4.03 & 9.42 & 51.97 & 1.69 & & \\
\hline Cananium sp. & 6.85 & 4.11 & 10.33 & 53.24 & 2.22 & & \\
\hline Softwood sawdust & 3.42 & 3.00 & 21.90 & 10.09 & 1.04 & 0.95 & \multirow{2}{*}{ [31] } \\
\hline Hardwood sawdust & 3.51 & 3.51 & 22.81 & 10.36 & 1.25 & 0.96 & \\
\hline $\begin{array}{l}\text { cupuaçu } \\
\text { exocarp } \\
\text { supplemented with } \\
\text { rice bran. } \mathrm{g} / \mathrm{kg}\end{array}$ & 0.21 & 30.85 & 24.19 & 10.39 & 1.46 & & [32] \\
\hline Fig tree & 27.33 & & 1.18 & 0.88 & 13.31 & & \multirow{6}{*}{ [34] } \\
\hline Rain Tree & 30.69 & & 1.26 & 0.77 & 18.02 & & \\
\hline Mahogany tree & 31.98 & & 1.27 & 0.79 & 19.85 & & \\
\hline Ipil ipil tree & 31.92 & & 1.28 & 0.85 & 14.35 & & \\
\hline Eucalyptus tree & 31.47 & & 1.16 & 0.87 & 17.26 & & \\
\hline Mixture of sawdust & 31.25 & & 1.13 & 0.91 & 15.23 & & \\
\hline
\end{tabular}

\section{MACRO NUTRIENT CONTENT OF PLEUROTUS OSTREATUS}

The chemical composition of mushrooms determines their nutritional values. It differs according to species but also depend among others thing include included substratum. In fact, mushrooms can supply nutritive constituents important in the human nutrition; such as dietary fibre; protein, carbohydrate etc...

\subsection{Protein Content}

Protein content mushrooms is constituted of more than half of total nitrogen and depends on several factors among which the composition of substrate. This content varies between 0,8 and 3,5 $\mathrm{g} / 100 \mathrm{~g}$ of fresh matter [35] or between 19,0 and 39,0 g/100g dry matter Coskuner and Ozdemir [36]. Victor and Olatomiwa [30] reported that the protein composition of the Pleurotus samples produced on Pycnanthus Ongoleubis, Ceiba pentandra, Cananium sp. 
sawdusts ranges between 20.03 to $20.11 \%$. These results are in the same line as Bonatti, et al. [24] who produced Pleurotus ostreatus on cotton waste. Comparatively, Ogundele, et al. [31] showed that the protein content of the mushroom harvested from the hardwood sawdust (Anogeissus leiocarpus) was higher $(26.67 \% \mathrm{db})$ than that harvested from softwood sawdust $(17.68 \% \mathrm{db})$. On the other hand, Pleurotus cultivated on rice bran, Pineapple crown, cupuaçu exocarp, pineapple peel, açai seed and sawdust substrates presented $17.37 \%, 16.14 \%, 12.42 \%, 7.99 \%$, $7.85 \%, 5.44 \%$, of protein contents respectively [33]. On cottonseed waste, the results of crude protein obtained were $25.91 \%$, which are in the range reported by Rashad, et al. [37]. Akindahunsi and Oyetayo [38] also reported $28.52 \%$ of crude protein for fresh P. ostreatus.

\subsection{Crude Fibre Content}

Studies carried out by different authors showed that crude fibre content depends on the substrate on which Pleurotus is produced. Specifically, they obtained $18.50 \%, 17.51 \%, 12,79 \% 10.66 \%$, and 9.59\% respectively cultivated on cottonseed wastes [24] cupuaçu exocarp supplemented with rice bran [33] Pycnanthus ongoleubi and Ceiba pentandra [30] softwood sawdust (Daniellia oliveri \%) and hardwood sawdust (Anogeissus leiocarpus) [31]. From these results, we can notice that the highest crude fibre content is obtained with Pleurotus cultivated on cottonseed wastes and the lowest on hardwood.

\subsection{Fat Content}

Oyster mushroom has been reported to have low fat [8,39]. This is confirmed with the report of Victor and Olatomiwa [30] whose obtain fat content (2.31\% to $3.09 \%$ ) cultivated on Ceiba pentandra and Pycnanthus ongoleubis respectively. The crude fat content of mushroom from hardwood sawdust (Anogeissus leiocarpus) were lower $1.72 \%$ $\mathrm{db}$ compare to mushroom harvested from softwood sawdust (Daniellia oliveri) (1.81\%) [31]. With rice bran substrate, fat contents was $3.8 \%$ [32]. To conclude, Pleurotus cultivated on hardwood sawdust (Anogeissus leiocarpus) had the lowest fat content $(1.72 \%)$

\subsection{Carbohydrate Content}

On a dry basis, constitutive of the fungus, the carbohydrate content was higher in Pleurotus ostreatus grown on acai seeds (85.69\%), cupuaçu exocarp (71.09\%) and pineapple skin. (67.96\%). This content is relatively lower in Pleurotus grown on cotton waste $(48.35 \%)$, on Pycnanthus ongoleubis $(45.75 \%)$ and on Ceiba pentandra and Cananium sp (41.87\% and $44.56 \%$ respectively) [30]. These latter results are similar to the report by Ragunathan and Swaminathan [22] that the carbohydrate content of Pleurotus ostreatus is between 40.60 and 53.30\%. Also, the carbohydrate content of sawdust fungi (Anogeissus leiocarpus) was $41.57 \%$ lower than that of softwood sawdust (Daniellia oliveri) $(52.04 \% \mathrm{db})[31]$.

\subsection{Amino Acid Composition}

The most abundant amino acids reported by Victor and Olatomiwa [30] are glutamic acid, arginine, aspartic acid, threonine, leucine and alanine. Chirinang and Intarapichet [39] previously reported that these amino acids were more abundant in P. ostreatus and P. sajor-caju. However, glutamic acid (9.01 g/ $100 \mathrm{~g}$ at $10.3 \mathrm{~g} / 100 \mathrm{~g})$ was more abundant in $P$. ostreatus grown on a woody substrate. These results are consistent with the work of Mendez, et al. [40] who worked on the same types of substrate. Bender [41] reports that P. ostreatoroseus contains eight essential amino acids. In P. ostreatoroseus DPUA 1720, the most abundant were valine, lysine and leucine ranging from 1.134 to $1.304 \mathrm{~g} / 100 \mathrm{~g}$. The content of glutamate and aspartate (non-essential amino acids) was 3.592 and $2.061 \mathrm{~g} / 100 \mathrm{~g}$. However, the amino acid concentration of Flammulina velutipes and P. ostreatus grown in wheat, cotton, and soybean was lower [42,43]. 
Table-2. Macro nutrients content of Pleurotus ostreatus harvested from differents substrates

\begin{tabular}{|c|c|c|c|c|c|c|c|}
\hline \multicolumn{2}{|c|}{ Substrate (\%) } & Protein & Carbohydrate & Fat & Amino acid & Crude fibre & References \\
\hline \multicolumn{2}{|l|}{$\begin{array}{l}\text { Pycnanthus } \\
\text { Ongoleubis }\end{array}$} & 20.11 & 45.74 & 3.09 & 42.30 & 17.51 & \multirow{3}{*}[30]{} \\
\hline \multicolumn{2}{|l|}{$\begin{array}{l}\text { Ceiba } \\
\text { Pentandra }\end{array}$} & 20.03 & 41.8 & 2.31 & 40.56 & 17.35 & \\
\hline \multicolumn{2}{|l|}{ Cananium sp. } & 20.06 & 45.74 & 2.76 & 35.97 & 17.42 & \\
\hline \multicolumn{2}{|c|}{ Softwood sawdust } & 17.68 & 52.04 & 1.81 & & 10.66 & \multirow{2}{*}[31]{} \\
\hline \multicolumn{2}{|c|}{ Hardwood sawdust } & 26.67 & 41.57 & 1.72 & & 11.05 & \\
\hline \multicolumn{2}{|c|}{$\begin{array}{l}\text { Cupuaçu } \\
\text { exocarp supplemented with rice } \\
\text { bran. }\end{array}$} & 23.53 & 46.98 & 3.08 & 20.27 & 12.79 & {$[32]$} \\
\hline Cotton seed & waste & 25.91 & 42.14 & 2.18 & & 10.41 & {$[44]$} \\
\hline \multirow{6}{*}{$\begin{array}{l}\text { sawdust } \\
\text { substrates }\end{array}$} & Fig tree & 25.35 & 40.19 & 4.46 & & 18.96 & \multirow{6}{*}[34]{} \\
\hline & Rain Tree & 26.24 & 41.26 & 4.25 & & 19.25 & \\
\hline & Mahogany tree & 26.73 & 42.36 & 3.75 & & 17.13 & \\
\hline & $\begin{array}{l}\text { Ipil } \\
\text { ipil tree }\end{array}$ & 27.30 & 40.23 & 3.67 & & 20.30 & \\
\hline & Eucalyptus tree & 26.83 & 40.23 & 3.43 & & 20.53 & \\
\hline & $\begin{array}{l}\text { mixture of all } \\
\text { sawdust }\end{array}$ & 26.46 & 39.67 & 3.47 & & 17.37 & \\
\hline
\end{tabular}

Source: [30-32, 34, 44]

\section{FUNCTIONAL PROPERTY}

\subsection{Moisture Content}

Water is one of the main components of mushroom. Chang and Miles [45] had reported that the moisture content of dried mushrooms range from 9 - 13\%. These results are confirmed by Victor and Olatomiwa [30] who obtain moisture content of dried Pleurotus ostreatus ranges from $9.00 \%$ to $10.72 \%$. The moisture content of Pleurotus ostreatus harvested from hardwood sawdust (Anogeissus leiocarpus) [32] was higher $\left(\begin{array}{llll}8.93 \% & \mathrm{db}\end{array}\right)$ than that harvested from softwood sawdust (Daniellia oliveri) $(7.88 \% \mathrm{db})$ Ogundele, et al. [31]. On cottonseed waste the moisture content was 8.45\%, which is in the range of report of Manzi, et al. [8] for the fruiting bodies of fresh P.ostreatus cultivated on different lignocellulosic agro-wastes. Similar results were also reported by Patil, et al. [46].

\subsection{Ash Content}

According to Ogundele, et al. [31] there was no significant difference at $\mathrm{p}<0.05$ in values of ash content of mushroom harvested from the substrates. Although, in an early studies, Tamiris, et al. [32] observe significant difference in values of ash content: $9.14,4.53,3.96$ and $3.45 \%$ in rice bran, cupuaçu exocarp, pineapple crown and pineapple peel, respectively.

Table-3. Macro nutrient content of Pleurotus ostreatus harvested from differents substrates

\begin{tabular}{|c|c|c|c|c|}
\hline \multicolumn{2}{|c|}{ Substrate (\%) } & ASH & MOISTURE & References \\
\hline \multicolumn{2}{|c|}{ Pycnanthus ongoleubis } & 4.75 & 9.25 & \multirow{3}{*}[30]{} \\
\hline \multicolumn{2}{|c|}{ Ceiba pentandra } & 8.19 & 10.72 & \\
\hline \multicolumn{2}{|c|}{ Cananium sp. } & 6.76 & 2.22 & \\
\hline \multicolumn{2}{|c|}{ Softwood sawdust } & 9.59 & 7.88 & \multirow{2}{*}[31]{} \\
\hline \multicolumn{2}{|c|}{ Hardwood sawdust } & 9.83 & 8.93 & \\
\hline \multicolumn{2}{|c|}{ Cupuaçu exocarp supplemented with rice bran. } & 6.49 & 7.15 & {$[32]$} \\
\hline \multicolumn{2}{|c|}{ cottonseed waste } & $10.91 \pm 1.22$ & $8.45 \pm 1.65$ & {$[44]$} \\
\hline \multirow{6}{*}{$\begin{array}{l}\text { sawdust } \\
\text { substrates }\end{array}$} & Fig tree & 11.0 & 89.47 & \multirow{6}{*}[34]{} \\
\hline & Rain Tree & 9.0 & 90.13 & \\
\hline & Mahogany tree & 10.0 & 89.97 & \\
\hline & $\begin{array}{l}\text { Ipil } \\
\text { ipil tree }\end{array}$ & 8.5 & 90.13 & \\
\hline & Eucalyptus tree & 9.0 & 90.17 & \\
\hline & mixture of all sawdust & 13.0 & 90.20 & \\
\hline
\end{tabular}




\section{CONCLUSION}

This study observed that there is variation in proximate composition of the Pleurotus ostreatus grown and harvested from different substrates, which could be attributed to the nutritional composition of the substrate where these were cultivated.

Funding: This research did not receive any specific grant from funding agencies in the public, commercial, or not-for-profit sectors.

Competing Interests: The authors declare that they have no competing interests.

Contributors/Acknowledgement: All authors contributed equally to the conception and design of the study.

\section{REFERENCES}

[1] Q. Mandeel, A. Al-Laith, and S. Mohamed, "Cultivation of oyster mushrooms (Pleurotus spp.) on various lignocellulosic wastes," World Journal of Microbiology and Biotechnology, vol. 21, pp. 601-607, 2005. View at Google Scholar | View at Publisher

[2] S. Chang, "World production of cultivated edible and medicinal mushrooms in 1997 with emphasis on< i> Lentinus edodes</i>(Berk.) Sing, in China," International Journal of Medicinal Mushrooms, vol. 1, pp. 291-300, 1997.

[3] M. Obodai, J. Cleland-Okine, and K. Vowotor, "Comparative study on the growth and yield of pleurotus ostreatus mushroom on different lignocellulosic by-products," Journal of Industrial Microbiology and Biotechnology, vol. 30, pp. 146-149, 2003. View at Google Scholar $\mid$ View at Publisher

[4] C. Sánchez, "Cultivation of pleurotus ostreatus and other edible mushrooms," Applied Microbiology and Biotechnology, vol. 85, pp. 13211337, 2010. View at Google Scholar | View at Publisher

[5] H. K. P. S. G. Garcha. Nutritional importance of mushrooms. In: Mushroom biology and mushroom products Chinese University,, B. J. C. S. E. Chang S, Ed., Hong Kong: Chinese University Press, 1993.

[6] T. Asmamaw, T. Abebe, and K. Gebre, "Optimization of oyster (Pleurotus ostreatus) mushroom cultivation using locally available substrates and materials in Debre Berhan,Ethiopia," Journal of Applied Biology ङ Biotechnology, vol. 3, pp. 15-20, 2015. View at Google Scholar

[7] M. G. G. M. E. D. C. M. G. C. E. Justo, "Chemical composition of three mushrooms strains ( Pleurotus Ostreatus) (Composição química de três cepas mexicanas de setas (Pleurotus Ostreatus)," Archive Latin Nutrition, vol. 48, pp. 359-363, 1998.

[8] P. Manzi, L. Gambelli, S. Marconi, V. Vivanti, and L. Pizzoferrato, "Nutrients in edible mushrooms: An inter-species comparative study," Food Chemistry, vol. 65, pp. 477-482, 1999. View at Google Scholar $\mid$ View at Publisher

[9] M. Bonatti, P. Karnopp, H. M. Soares, and S. A. Furlan, "Evaluation of Pleurotus ostreatus and Pleurotus sajor-caju nutritional characteristics when cultivated in different lignocellulosic wastes," Food Chemistry, vol. 88, pp. 425-428, 2004. View at Google Scholar | View at Publisher

[10] M. N. Shashirekha, S. Rajarathnam, and Z. Bano, "Effects of supplementing rice straw growth substrate with cotton seed on the analytical characteristics of the mushroom Pleurotus florida (Block \&Tsao)," Food Chemistry, vol. 92, pp. 255-259, 2005. View at Google Scholar | View at Publisher

[11] W. Pedra and R. Marino, "Axenic cultivation of Pleurotus spp. in coconut exocarp sawdust supplemented with rice bran ou wheat bran (Cultivo axênico de Pleurotus spp. em serragem da casca de coco (Cocos nucifera Linn.) suplementada com farelo de arroz e/ou," Archives of the Biological Institute, vol. 73, pp. 219-225, 2006.

[12] W. Pedra, M. Carnelossi, G. Silva, P. Yaguiu, M. L. Lira, G. B. Gonçalves, and R. Marino, "Chemical and sensorial analysis of Pleurotus ostreatus cultivated in coconut exocarp supplemented with wheat bran and/or rice bran (Análise química e sensorial de Pleurotus ostreatus cultivado em casca de coco suplementada com farel," Archives of the Biological Institute, vol. 76, pp. 91-98, 2009. View at Google Scholar

[13] J. Menolli, T. Asai, M. Capelari, and L. Paccola-Meirelles, "Morphological and molecular identification of four brazilian commercial isolates of Pleurotus spp. and cultivation on corncob," Brazilian Archives of Biology and Technology, vol. 53, pp. 397-408, 2010. View at Google Scholar | View at Publisher 
[14] A. Omarini, V. Nepote, N. Grosso, J. Zygadlo, and E. Albertó, "Sensory analysis and fruiting bodies characterisation of the edible mushrooms pleurotus ostreatus and polyporus tenuiculus obtained on leaf waste from the the essential oil production industry," International Journal of Food Science \& Technology, vol. 45, pp. 466-474, 2010. View at Google Scholar | View at Publisher

[15] A. Eira, Edible fungi (Fungos comestíveis). In: Fungi: An introduction to biology, biochemistry and biotechnology (Fungos: uma introdução à biologia, bioquímica e biotecnologia), ( Azevedo JL (Ed.) ed.). Caxias do Sul: Educs.: Espósito E, 2004.

[16] J. Cui, K. K. T. Goh, R. Archer, and H. Singh, "Characterisation and bioactivity of protein-bound polysaccharides from submergedculture fermentation of coriolus versicolor Wr-74 and ATCC-20545 strains," Journal of Industrial Microbiology \&̊ Biotechnology, vol. 34, pp. 393-402, 2007. View at Google Scholar | View at Publisher

[17] S. Silva, S. Martins, A. Karmali, and E. Rosa, "Production, purification and characterisation of polysaccharides from pleurotus ostreatus with antitumour activity," Journal of the Science of Food and Agriculture, vol. 92, pp. 1826- 1832, 2012. View at Google Scholar | View at Publisher

[18] M. C. S. Da Silva, J. Naozuka, J. M. R. da Luz, L. S. de Assunção, P. V. Oliveira, M. C. D. Vanetti, D. M. S. Bazzolli, and M. C. M. Kasuya, "Enrichment of pleurotus ostreatus mushrooms with selenium in coffee husks," Food Chemistry, vol. 131, pp. 558-563, 2012. View at Google Scholar | View at Publisher

[19] A. Tesfaw, A. Tadesse, and G. Kiros, "Optimization of oyster (Pleurotus ostreatus) mushroom cultivation using locally available substrates and materials in Debre Berhan, Ethiopia," Journal of Applied Biology \& Biotechnology, vol. 3, pp. 15-20, 2015. View at Google Scholar | View at Publisher

[20] K. Ananbeh and A. Almomany, "Production of oyster mushroom (Pleurotus Ostreatus) on tomato tuff agrowaste," Dirasat Agricultural Sciences, vol. 35, pp. 133-138, 2008. View at Google Scholar

[21] X. Li, Y. Pang, and R. Zhang, "Compositional changes of cotton seed hull substrate during P. ostreatus growth and the effects on the feeding value of the spent substrate," Bioresource Technology, vol. 80, pp. 157-161, 2001. View at Google Scholar | View at Publisher

[22] R. Ragunathan and K. Swaminathan, "Nutritional status of Pleurotus spp. grown on various agro-wastes," Food Chemistry, vol. 80, pp. 371-375, 2003. View at Google Scholar | View at Publisher

[23] E. Moda, J. Horii, and M. Spoto, "Edible mushroom pleurotus sajor-caju production on washed and supplemented sugarcane bagasse," Science Agriculture, vol. 62, pp. 127-132, 2005. View at Google Scholar | View at Publisher

[24] M. Bonatti, P. Karnopp, H. Soares, and S. Furlan, "Studies of pleurotus ostreatus and pleurotus sajor-caju mushrooms composition cultivated in banana straw (Estudo da composição de cogumelos das espécies Pleurotus ostreatus e Pleurotus sajor-caju cultivados em palha de bananeira)," Journal of Environmental Health, vol. 4, pp. 31-35, 2003. View at Google Scholar

[25] C. K. R. Shibata and I. M. Demiate, "Cultivation and analysis of chemical composition of the mushroom Agaricus blazei (Cultivo e análise da composição química do cogumelo do sol (Agaricus blazei Murril)). Publicatio UEPG," Biological and Health Science, vol. 9, pp. $21-32,2003$.

[26] H. Genccelep, Y. Uzun, T. R. Y. Tunc, and Demirel, "Determination of mineral contents of wild-grown edible mushrooms," Food Chemistry, vol. 113, pp. 1033-1036, 2009. View at Google Scholar | View at Publisher

[27] M. Gucia, A. Kojta, S. G. Jarzyn, E. Rafal, M. Roszak, and Osiej, "Multivariate analysis of mineral constituents of edible parasol mushroom (Macrolepiota procera) and soils beneath fruiting bodies collected from Northern Poland," Environmental Science and Pollution Research, vol. 19, pp. 416-431, 2012. View at Google Scholar | View at Publisher

[28] B. Emilia, J. Grazyna, and L. Zofia, "Edible mushroom as a source of valuable nutritive constituents," Acta Scientiarum Polonorum Technologia Alimentaria, vol. 5, pp. 5-20, 2006. View at Google Scholar

[29] T. Watanabe, N. Tsuchihasi, K. Takai, K. Tanaka, and A. Suzuki, "Effects of ozone exposure during cultivation of oyster mushroom (Pleurotus ostreatus) on chemical components of the fruit bodies," Journal of the Japanese Food Science and Technology, vol. 41, pp. 705708, 1994. View at Google Scholar | View at Publisher

[30] O. O. Victor and O. A. Olatomiwa, "Micro and macronutrient properties of pleurotus ostreatus (Jacq: Fries) cultivated on different wood substrates," Jordan Journal of Biological Sciences, vol. 6, pp. 223 - 226, 2013. View at Google Scholar | View at Publisher 
[31] S. Ogundele, I. Salawu, O. Abdulraheem, and Bamidele, "Nutritional composition of oyster mushroom (Pleurotus ostreatus) Grown on softwood (Daniella oliveri) sawdust and hardwood (Anogeissus leiocarpus) sawdust," British Journal of Applied Science \& Technology, vol. 20, pp. 1-7, 2016. View at Google Scholar | View at Publisher

[32] R. B. F. Tamiris, F. Mircella, S. Raimundo, d. A. Taciana, and F. Maria, "Cultivation and nutritional studies of an edible mushroom from North Brazil," African Journal of Microbiology Research, vol. 9, pp. 1814-1822, 2015. View at Google Scholar | View at Publisher

[33] F. Oyetayo, Nutritional and toxicological studies on cultivated and wildly obtained edible mushroom, pleurotus sajorcaju. Akure: Federal University of Technology, 2005.

[34] K. B. Debu, K. P. Ratan, M. Nuruddin, and U. A. Kamal, "Comparative study on nutritional composition of oyster mushroom (Pleurotus ostreatus Fr.) cultivated on different sawdust substrates," Bioresearch Communication, vol. 1, pp. 93-98, 2015. View at Google Scholar

[35] Florczak and Lasotaw, "Cadmium uptake and binding by artificially cultivated Pleurotus ostreatus," Bromatology Chemistry Toksy, vol. 28, pp. 17-23, 1995. View at Google Scholar

[36] Y. Coskuner and Y. Ozdemir, "Acid and EDTA blanching effect on the essential element content of mushrooms (Agaricus bisporus)," Journal of the Science of Food and Agriculture, vol. 80, pp. 2074-2076, 2000. View at Google Scholar | View at Publisher

[37] M. Rashad, W. H. Abdou, A. Shousha, M.M., and EL-Sahed, "Utilisation of some food processing wastes for production of pleurotus ostreatus pectinases," Advances in Food Sciences, vol. 31, pp. 151-157, 2009. View at Google Scholar

[38] A. Akindahunsi and F. Oyetayo, "Nutrient andantinutrient distribution of edible mushroom, Pleurotustuber-regium (fries) singer," LWT-Food Science and Technology, vol. 39, pp. 548 - 553, 2006. View at Google Scholar | View at Publisher

[39] P. Chirinang and K. Intarapichet, "Amino acids and antioxidant properties of theoyster mushrooms, pleurotus ostreatus and Pleurotus sajor-caju," Science Asia, vol. 35, pp. 326 - 331, 2009. View at Google Scholar

[40] L. A. Mendez, C. Castro, R. B. Casso, and C. Leal, "Effect of substrate and harvest on the amino acid profile of oyster mushroom (Pleurotus ostreatus)," Journal of Food Composition and Analysis, vol. 18, pp. 447 -450, 2005. View at Google Scholar | View at Publisher

[41] A. Bender, Dictionary of nutrition and food tecnology (Dicionário de nutrição e tecnologia de alimentos), 4th ed. São Paulo: Editora Roca Ltda, 2004 .

[42] A. Dundar, H. Acay, and A. Yildiz, "Effect of using different lignocellulosic wastes for cultivation of Pleurotus ostreatus (Jacq.) P. Kumm. on mushroom yield, chemical composition and nutritional value," African Journal of Biotechnology, vol. 8, pp. 662-666, 2009. View at Google Scholar

[43] K. Lee, I. Yun, K. Kim, S. Lim, H. Hamb, W. Eumc, and J. Joo, "Amino acid and fatty acid compositions of Agrocybe chaxingu, an edible mushroom," Journal of Food Composition and Analysis, vol. 24, pp. 175-178, 2011. View at Google Scholar|View at Publisher

[44] T. D. Kumela and A. Solomon, "Nutritional quality of oyster mushroom (Pleurotus ostreatus) as affected by osmotic pretreatments and drying methods," Food Science छ Nutrition, vol. 5, pp. 989-996, 2017. View at Google Scholar | View at Publisher

[45] S. Chang and P. Miles, Mushrooms: Cultivation, nutritional value, medicinal effect, and environmental impact, 2nd ed. Boca Raton: CRC Press, 2004.

[46] S. Patil, S. Ahmed, S. Telang, and M. Baig, "The nutritional value of pleurotus ostreatus (Jacq. : fr.) kumm cultivated on different lignocellulosic agrowastes," Innovative Romanian Food Biotechnology, vol. 7, pp. 66-76, 2010. View at Google Scholar

Views and opinions expressed in this article are the views and opinions of the author(s), Current Research in Agricultural Sciences shall not be responsible or answerable for any loss, damage or liability etc. caused in relation to/arising out of the use of the content. 